\title{
Radiation recall dermatitis induced by sorafenib
}

\author{
A case study and review of the literature
}

\author{
Sonja Stieb $^{1,2} \cdot$ Oliver Riesterer $^{1}$ - Cornelia Brüssow ${ }^{1} \cdot$ Bernhard Pestalozzi $^{3}$. \\ Matthias Guckenberger ${ }^{1} \cdot$ Stefan Weiler $^{4}$
}

Received: 29 October 2015 / Accepted: 28 January 2016 / Published online: 23 February 2016

(C) Springer-Verlag Berlin Heidelberg 2016

\begin{abstract}
Background Radiation recall dermatitis (RRD) is an acute inflammatory reaction confined to previously irradiated skin, mainly subsequent to the administration of certain chemotherapeutics. Here we present a rare case of RRD induced by the oral multikinase inhibitor sorafenib.

Case report A 77-year-old male with hepatocellular carcinoma was irradiated at ten different sites for bone metastases with 20-36 Gray in 5-12 fractions from January to March 2015. Sorafenib $400 \mathrm{mg}$ was administered twice daily from mid-March. One week later the patient presented with fever and erythematous lesions on the right upper arm,
\end{abstract}

Stefan Weiler

stefan.weiler@usz.ch

Sonja Stieb

sonja.stieb@psi.ch

Oliver Riesterer

oliver.riesterer@usz.ch

Cornelia Brüssow

cornelia.bruessow@usz.ch

Bernhard Pestalozzi

bernhard.pestalozzi@usz.ch

Matthias Guckenberger

matthias.guckenberger@usz.ch

1 Department of Radiation Oncology, University Hospital Zurich, Rämistrasse 100, 8091 Zurich, Switzerland

2 Center for Proton Therapy, Paul Scherrer Institute, Villigen PSI, 5232 Villigen, Switzerland

3 Department of Oncology, University Hospital Zurich, Rämistrasse 100, 8091 Zurich, Switzerland

4 Department of Clinical Pharmacology and Toxicology, University Hospital and University of Zurich, Rämistrasse 100, 8091 Zurich, Switzerland mandible, and trunk. All skin symptoms were confined to previously irradiated areas. After RRD was diagnosed by exclusion of other causes and skin biopsy, sorafenib was paused. With the administration of topical corticosteroids and oral antihistamines, the skin reaction subsided within several days. Sorafenib was readministered after 3 weeks, which did not lead to recurrence of RRD but did cause fluctuating fever.

Discussion Only four other such cases have been reported in the literature and WHO pharmacovigilance database on individual case safety reports. The current report is the first to show a potential relationship between the severity of sorafenib-induced RRD and radiation dose, histopathological features, and simultaneous acute radiation dermatitis and mucositis.

Conclusion RRD induced by sorafenib is a rare phenomenon, but should be considered in patients showing erythematous skin lesions 1-2 weeks after initiation of the drug, predominantly in areas where skin has been irradiated with an equivalent dose $\geq 30$ Gy. Discontinuation of sorafenib with possible readministration should be evaluated with respect to the clinical situation and severity of reaction.

Keywords Hepatocellular carcinoma - Radiotherapy · Chemotherapy $\cdot$ Toxicity $\cdot$ Erythema

\section{Recall-Strahlendermatitis durch Sorafenib}

Eine Fallstudie und Literaturübersicht

\section{Zusammenfassung}

Hintergrund Recall-Strahlendermatitis (RRD) ist eine akute Entzündungsreaktion der Haut in zuvor bestrahlten Arealen, welche meist nach Einnahme bestimmter Chemo- 
therapeutika auftritt. Nachfolgend präsentieren wir einen seltenen Fall von RRD unter Therapie mit dem Multikinaseinhibitor Sorafenib.

Fallbeschreibung Ein 77-jähriger, männlicher Patient mit ossär metastasiertem hepatozellulärem Karzinom wurde zwischen Januar und März 2015 an insgesamt 10 verschiedenen Lokalisationen mit 20-36 Gy in 5-12 Fraktionen bestrahlt. Ab Mitte März wurde $400 \mathrm{mg}$ Sorafenib 2-mal täglich verabreicht. Eine Woche später entwickelte der Patient Fieber und erythematöse Hautläsionen am rechten Oberarm, Unterkiefer und Rumpf. Die Hautveränderungen waren allesamt auf zuvor bestrahlte Areale begrenzt. Nach Ausschluss anderer Ursachen mittels Biopsie einer der Hautveränderungen wurde die klinische Diagnose einer RRD gestellt. Sorafenib wurde pausiert und topische Kortikosteroide sowie orale Antihistaminika verabreicht, woraufhin die Hautreaktionen abklangen. Eine erneute Gabe von Sorafenib nach insgesamt 3-wöchiger Pause führte zu keiner neuerlichen Hautreaktion, löste jedoch fluktuierendes Fieber aus.

Diskussion Weltweit wurden bislang nur vier weitere Fälle von RRD unter Sorafenib berichtet. Im vorliegenden Fall werden erstmals ein potentieller Zusammenhang des Schweregrads der RRD unter Sorafenib mit der Bestrahlungsdosis der Haut, die histopathologischen Veränderungen sowie eine gleichzeitig vorliegende akute Strahlendermatitis und Mukositis dargestellt.

Schlussfolgerung Durch Sorafenib hervorgerufene RRD ist ein seltenes Phänomen, das in den bestrahlten Hautarealen, vornehmlich nach einer Äquivalentdosis von $\geq 30 \mathrm{~Gy}$, als erythematöse Hautreaktion 1-2 Wochen nach Therapiebeginn mit der Substanz auftritt. Eine Therapiepause mit möglichem Wiederbeginn von Sorafenib sollte abhängig von der klinischen Situation und dem Schweregrad der Reaktion evaluiert werden.

Schlüsselwörter Hepatozelluläres Karzinom ·

Strahlentherapie $\cdot$ Chemotherapie $\cdot$ Toxizität $\cdot$ Erythem

Radiation recall dermatitis (RRD) is defined as an acute inflammatory reaction confined to previously irradiated skin after the administration of certain drugs, mostly classical chemotherapeutics, usually occurring months or even years after radiotherapy [1].

Sorafenib is an oral multikinase inhibitor and targeted anticancer substance. Sorafenib is indicated for treatment of unresectable hepatocellular carcinoma (HCC), advanced ${ }^{133}$ I-refractory thyroid carcinoma, or advanced pretreated renal cell carcinoma [2]. The most common adverse effects of sorafenib are gastrointestinal, with abdominal pain, diarrhea, and nausea; hepatic, with elevated levels of liver enzymes; and dermatologic, with palmar-plantar erythro- dysesthesia (hand-foot reaction), alopecia, and rash [3-5]. Here we present a rare case of RRD induced by sorafenib in a patient irradiated for several bone metastases from HCC. A systematic review of published cases in the scientific literature and the WHO pharmacovigilance database was conducted to identify risk factors, signs, and course of this reaction, as well as outcome.

\section{Case study}

A 77-year-old male Caucasian (weight $67 \mathrm{~kg}$; height $160 \mathrm{~cm}$; body mass index, BMI $\left.26 \mathrm{~kg} / \mathrm{m}^{2}\right)$ with hepatitis C-associated HCC (diagnosed April 2014) received radiation to several metastatic bone sites between January and March 2015. Radiation dose was 20-36 Gy delivered in 5-12 fractions (Table 1), which resulted in a good analgesic effect with improvement of the patient's mobility. Sorafenib was started at a dosage of $200 \mathrm{mg}$ orally twice daily in mid-March, with slow dose increments. Long-term comedication included amlodipine, metoprolol, hydrochlorothiazide for hypertension, tamsulosin for prostatic hyperplasia, oxycodone for pain, and esomeprazole for gastric ulcer prophylaxis.

One week after initiation of sorafenib the patient presented with fever $\left(38.2{ }^{\circ} \mathrm{C}\right)$, rising C-reactive protein (CRP; $23 \mathrm{mg} / \mathrm{l}$ ), and a painless erythematous lesion at the right elbow where he had undergone surgery for pathologic fracture and received postoperative irradiation with 12 fractions of3 Gy. Blood pressure, heart rate, and oxygen saturation were unchanged compared to baseline values (blood pressure 150/80 $\mathrm{mmHg}$; pulse rate $91 / \mathrm{min}$; oxygen saturation, $\mathrm{SpO}_{2}$ 92\%). Assuming a local skin infection, antibiotics ( $1 \mathrm{~g}$ amoxicillin/200 $\mathrm{mg}$ clavulanic acid every $8 \mathrm{~h}$ i.v.) were started. As per schedule, the dose of sorafenib was escalated to $400 \mathrm{mg}$ twice daily and the erythema spread proximally into a distinct rectangular shape equivalent to the previous irradiation field during the following days. In addition, other skin lesions evolved, all of them in currently (acute radiation dermatitis, ARD) or previously irradiated areas (RRD) (Fig. 1; Table 1). RRD was suspected and sorafenib was stopped 1 week after the first symptoms occurred. Other affected skin areas included currently and previously irradiated areas such as the mandible, scapula, and spine. Multiple erythematous papules and plaques resulted in dermatitis grade 1-3 according to the Common Terminology Criteria for Adverse Events (CTCAE) version 4.03 [6]. The severity of dermatitis showed a potential relationship with the administered radiation dose, because $\geq$ grade 2 skin toxicity predominantly occurred when the maximal skin dose was above 30 Gy (Table 1). In addition, the patient developed urinary retention and severe mucositis CTCAE grade 2 . Topical therapy of the skin lesions with corticosteroids (betamethasone, clobetasol) and systemic oral antihista- 
Table 1 Details of all radiation treatments that led to either radiation recall dermatitis (RRD) or acute radiation dermatitis (ARD).

\begin{tabular}{|c|c|c|c|c|c|c|c|c|}
\hline RT volume & $\begin{array}{l}\text { RT fractions } \times \\
\text { dose/fraction } \\
\text { (Gy) }\end{array}$ & $\begin{array}{l}\text { Time interval } \\
\text { end of RT- } \\
\text { begin of skin } \\
\text { reaction (days) }\end{array}$ & $\begin{array}{l}\text { Time interval begin } \\
\text { of sorafenib-onset of } \\
\text { skin reaction (days) }\end{array}$ & RT technique & RRD/ARD & $\begin{array}{l}\text { CTCAE } \\
\text { grade }\end{array}$ & $\begin{array}{l}\text { Min. } \\
\text { PTV-skin } \\
\text { distance } \\
(\mathrm{cm})\end{array}$ & $\begin{array}{l}\text { Max. skin } \\
\text { dose; } \\
\text { EQD2, } \\
\alpha / \beta=8(\mathrm{~Gy})\end{array}$ \\
\hline Humerus (r) & $12 \times 3^{a}$ & 37 & 10 & $3 \mathrm{D}$ & RRD & 3 & $<0.5$ & 39.4 \\
\hline Scapula (1) & $6 \times 5$ & 59 & 17 & $3 \mathrm{D}$ & RRD & 2 & $<0.5$ & 40.5 \\
\hline 8th rib (r) & $5 \times 5$ & 40 & 17 & $3 \mathrm{D}$ & RRD & 2 & $<0.5$ & 30.2 \\
\hline T6 & $5 \times 7$ & 50 & 17 & RA & RRD & $0-1$ & 2.2 & 28.0 \\
\hline $\mathrm{T} 10$ & $5 \times 7$ & 57 & 17 & RA & RRD & $0-1$ & 1.2 & 25.8 \\
\hline $\mathrm{T} 3$ & $5 \times 7$ & 50 & 17 & RA & RRD & 0 & 5.0 & 19.8 \\
\hline SIJ (l) & $5 \times 4$ & 2 & 17 & $3 \mathrm{D}$ & $\mathrm{ARD}$ & 2 & 1.2 & 18.0 \\
\hline L1 & $5 \times 4$ & 2 & 17 & $3 \mathrm{D}$ & ARD & 1 & 1.8 & 21.8 \\
\hline Mandible (1) & $5 \times 4$ & 2 & 17 & $3 \mathrm{D}$ & $\mathrm{ARD}$ & 1 & $<0.5$ & 25.8 \\
\hline Acetabulum (1) & $5 \times 4$ & 2 & 17 & $3 \mathrm{D}$ & ARD & 0 & 5.7 & 8.6 \\
\hline
\end{tabular}

CTCAE common terminology criteria for adverse events [6], $R T$ radiotherapy, EQD2 Equivalent dose in 2-Gy fractions, $L$ lumbar vertebra, $l$ left, $r$ right, $R A$ rapid arc, $S I J$ sacroiliac joint, $T$ thoracic vertebra, $3 D$ three-dimensional conformal radiotherapy, $P T V$ planning target volume apostoperative radiotherapy

mines (fexofenadine $180 \mathrm{mg}$ twice daily) was administered. Blood cultures remained negative. The patient developed a generalized eczematous skin reaction with severe pruritus. Skin biopsy of an erythematous lesion located on the right chest revealed diffuse perivascular lymphohistiocytic infiltrate with few eosinophils in the corium, and apoptotic keratinocytes and distinct vacuolization in the junction zone (Fig. 2).

The skin reaction decreased within 14 days after termination of sorafenib. After an interval of 3 weeks, sorafenib was restarted at a reduced dosage of $200 \mathrm{mg}$ twice daily. The skin reaction did not worsen, but the patient developed fluctuating fever, so sorafenib was eventually discontinued after another week.

\section{Systematic review and discussion}

We present a case of increased skin toxicity and severe mucositis shortly after initiation of sorafenib, with worsening ARD in areas currently under treatment (acetabulum, SIJ, L1, mandible), and RRD in previously irradiated areas (scapula, humerus, T3, T6, T10, 8th rib; see Table 1).

The radiosensitizing effect of sorafenib in combination with radiotherapy has been shown in different cell lines [711]. Peters et al. reported on a patient receiving sorafenib and irradiation for lumbar metastasis of a renal cell carcinoma who died of severe bowel complications after radiotherapy [12].

In contrast to other cutaneous complications of molecularly targeted therapies, such as hand-foot skin reaction, $\mathrm{RRD}$ induced by sorafenib is a rare phenomenon. In large clinical trials in patients with HCC who received sorafenib in combination with radiotherapy, cases of RRD were not reported [13, 14]. Similarly, no known reactions have been reported after treatment of gliomas $[15,16]$, pancreatic cancer $[17,18]$, or sarcoma [19-21].

We performed a systematic search for RRD induced by sorafenib in MEDLINE ("radiation recall dermatitis sorafenib"; "recall sorafenib") and the WHO global database "VigiBase" ${ }^{\circledR}$ " on pharmacovigilance [22]. So far, only three cases have been reported in the literature (Table 2). Hsieh et al. described RRD in a patient with HCC after intensity-modulated radiotherapy (IMRT) of the liver with $48 \mathrm{~Gy}$ and start of sorafenib $300 \mathrm{mg}$ twice daily 10 days after SBRT. A well-defined skin lesion on the right upper abdomen appeared 1 week after the start of sorafenib and resolved 10 days after stopping the drug and local therapy with clobetasol propionate [23]. Oh and colleagues observed an erythematous lesion with dry desquamation on the right chest wall in a patient with HCC irradiated for a chest wall mass with 39 Gy. After completion of radiotherapy, sorafenib was started with $400 \mathrm{mg}$ twice daily and the skin lesion occurred after 14 days. Another 10 days later, the patient presented with a disseminated exanthematous rash and severe pruritus. Sorafenib was stopped and an oral antihistamine was prescribed. One week later, the symptoms resolved and sorafenib was restarted without any further skin reactions [24]. Chung et al. presented the case of a 38-year-old male with liver metastases treated with palliative radiotherapy (6fractions of 5 Gy). Sorafenib was started with $200 \mathrm{mg}$ twice daily 3 weeks after completion of radiotherapy. Several days later, the patient presented with pruritus of the left posterior flank, hyperpigmentation, and dry desquamation in the previously irradiated areas. Sorafenib $200 \mathrm{mg}$ twice daily was continued and a topical steroid cream was administered. The pruritus and skin reaction resolved 2-3 weeks later. The dose of sorafenib was escalated to $400 \mathrm{mg}$ twice daily. No further exacerbations of the RRD occurred [25]. In the pharmacovigilance 

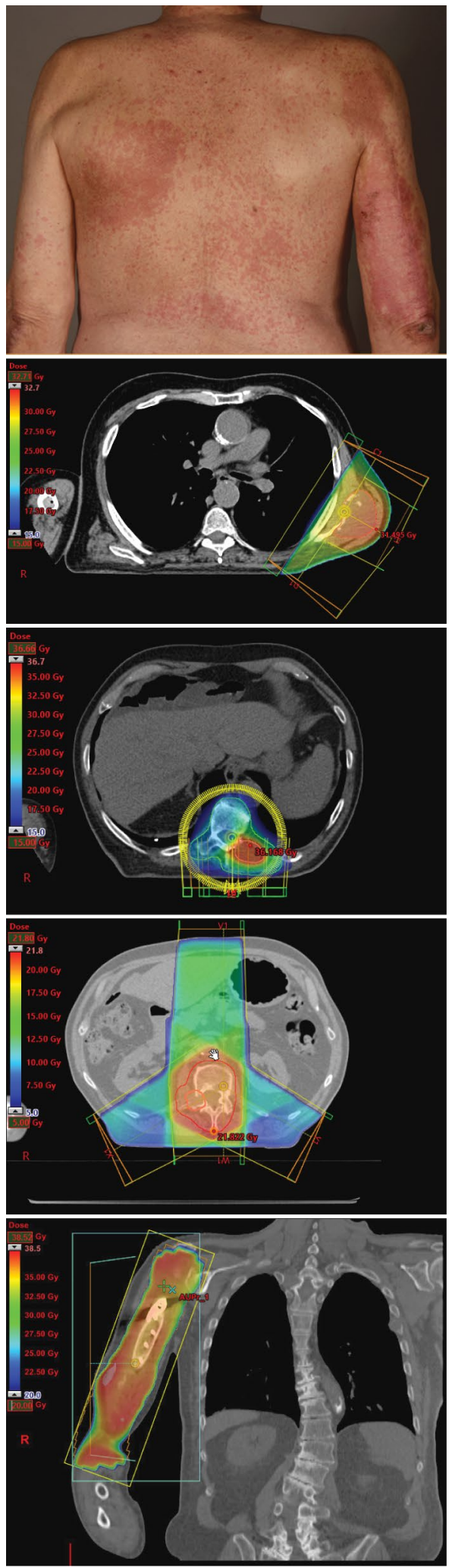

Fig. 1 Correlation of radiation recall dermatitis (right humerus, left scapula, T10) and acute radiation dermatitis (L1) with radiation fields database, only one other case of "recall phenomenon" and sorafenib was identified. Sorafenib was the only suspected drug in a 51-year-old male with metastatic renal cell carcinoma. Other reported symptoms included vesicular rash, swelling, tenderness, and pain. All reported patients with sorafenib-associated RRD were male, with a median age of 51 years and an average daily sorafenib dose of $575 \mathrm{mg}$ (range 300-800 mg). Symptoms started early after initiation of sorafenib, within 1-2 weeks.

The leading symptoms in the reported cases include erythematous skin lesions localized to areas of previous radiation exposure, marked by disseminated exanthematous rash, pruritus, and pain. RRD caused by other chemotherapeutics frequently occurred with an interval between radiotherapy and chemotherapy of less than 2 months [26]. Dose reduction or discontinuation of sorafenib together with systemic steroid therapy, antihistamines, and local treatment led to rapid improvement of symptoms. Rechallenge with the agent did not lead to recurrence of RRD.

There seems to be a radiation dose dependence of the severity of RRD. In contrast to other case reports with RRD after initiation of sorafenib, our patient was irradiated at several different locations with different radiation doses. He developed pronounced RRD in areas of the skin irradiated with a minimum of 30 Gy equivalent skin dose (Table 1). In particular, lesions near to the body surface and those irradiated with 3D-conformal radiotherapy are associated with high skin doses and are therefore more prone to RRD. Radiation-dose-dependent RRD has also been reported after treatment with bleomycin and docetaxel [27, 28]. Interestingly, the first occurrence of RRD in our patient was on the right upper arm, where he had received postoperative radiotherapy after osteosynthesis of a pathological humerus fracture. The RRD might have been triggered by the postoperative inflammatory environment. Other authors have hypothesized that potential triggers might be impaired epithelial function induced by the radiation effect on epithelial stem cells, changes in vascularization, or DNA repair [29].

Sorafenib is an inhibitor of multiple intracellular and cell surface kinases. It blocks Raf kinases which mediate cell proliferation and differentiation, and inhibits angiogenesis, including inhibition of vascular endothelial growth factor receptor [30]. Generally, the pathogenetic process of RRD is controversial-ranging from an idiosyncratic hypersensitivity reaction, to a defect in DNA repair and a direct toxic effect of the respective agent [31]. Skin biopsy in our patient, which was not performed in previous reports of RRD caused by sorafenib, demonstrated vacuolization of the dermoepidermal junction, and apoptotic keratinocytes with sparse perivascular infiltrate of lymphocytes and eosinophils (Fig. 2). The histological picture mimicked the pattern of graft-versus-host reactions of the skin or cutaneous drug allergies. An immune-mediated mechanism in the 


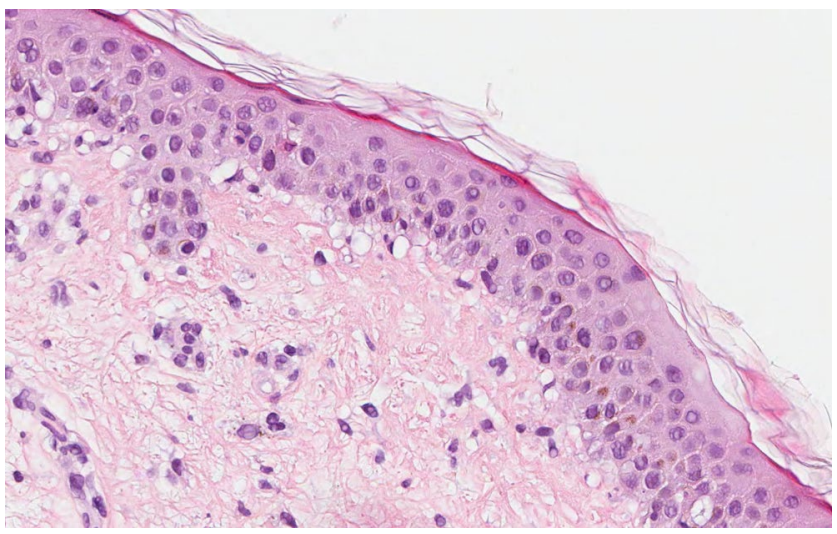

Fig. 2 Punch biopsy of a lesion at the right thoracic wall. The histopathological finding revealed a vacuolization of the dermoepidermal junction and apoptotic keratinocytes with sparse perivascular lymphocytic infiltrate and few eosinophils

present case might be plausible, with fluctuating fever as a systemic reaction after rechallenge with sorafenib. However, fever as an unspecific symptom is reported with an incidence of about $10 \%$ in patients treated with sorafenib.

Radiation recall reactions followed by sorafenib might not only be confined to skin reactions: cardiotoxicitiy has also been described [32]. Following irradiation of lung cancer and start of sorafenib 5 months after radiotherapy, a female patient presented with edema in the basal and midanterior wall of the heart muscle matching to the previously irradiated area [32]. In addition to augmentation of an acute skin reaction, sorafenib might also enhance acute mucosal toxicity. Our patient displayed enhanced mucosal toxicity in the oral cavity (maximum biologically effective dose, BED $30 \mathrm{~Gy} ; \alpha / \beta=8$ ) and the urethra/bladder neck (maximum BED $9 \mathrm{~Gy} ; \alpha / \beta=8$ ) with urinary retention in response to radiotherapy of the mandible and the pelvic region, which might be related to the radiosensitizing effect of sorafenib described above.

RRD is more commonly reported with conventional chemotherapeutic agents, including the anthracycline doxorubicin, the taxanes docetaxel and paclitaxel, and the antimetabolites gemcitabine and capecitabine [1]. However, RRD has also been described with other targeted cancer therapies in case reports or case series, such as for the BRAF inhibitor vemurafenib [33, 34], the EGFR inhibitor erlotinib [35], and the multitargeting tyrosine kinase inhibitor sunitinib [25]. The BED ranged from 20 to $57 \mathrm{~Gy}$, the interval between irradiation and targeted therapy from 1 to 1584 weeks, and the time to onset of RRD after targeted therapy start from 1 day to 87 weeks [36]. A clear correlation between the severity of RRD caused by sorafenib and the time interval between irradiation and the onset of symptoms (range 37-59 days) could not be demonstrated on the basis of our data (Table 1). However, the most severe RRD developed in the area of the first occurrence at the humerus, 10 days after start of sorafenib.

Table 2 Present case and summary of reported cases of radiation recall dermatitis (RRD) in ${ }^{a}$ MEDLINE and the ${ }^{b}$ WHO pharmacovigilance database "VigiBase ${ }^{\mathbb{R}}$ " [22]

\begin{tabular}{|c|c|c|c|c|c|c|c|c|}
\hline $\begin{array}{l}\text { Author, } \\
\text { year }\end{array}$ & $\begin{array}{l}\text { Age, } \\
\text { gender }\end{array}$ & Diagnosis & Radiotherapy & $\begin{array}{l}\text { Daily } \\
\text { sorafenib } \\
\text { dosage } \\
\end{array}$ & $\begin{array}{l}\text { Onset of RRD } \\
\text { after start of } \\
\text { sorafenib }\end{array}$ & Symptoms & RRD treatment & Outcome \\
\hline $\begin{array}{l}\text { Stieb, } \\
2015\end{array}$ & $77, \mathrm{~m}$ & $\mathrm{HCC}$ & $\begin{array}{l}\text { Bone } \\
\text { metastases } \\
20-36 \text { Gy }\end{array}$ & $2 \times 400 \mathrm{mg}$ & 1 week & $\begin{array}{l}\text { Erythematous rash, } \\
\text { eczematous dis- } \\
\text { semination, pruritus }\end{array}$ & $\begin{array}{l}\text { Topical ste- } \\
\text { roids and oral } \\
\text { antihistamines, } \\
\text { Sorafenib } \\
\text { discontinued }\end{array}$ & $\begin{array}{l}\text { Skin reaction decreased } \\
\text { within } 2 \text { weeks }\end{array}$ \\
\hline $\begin{array}{l}\text { Hsieha }^{\mathrm{a}} \\
2014\end{array}$ & $63, \mathrm{~m}$ & $\mathrm{HCC}$ & $\begin{array}{l}\text { Liver SBRT } \\
6 \times 8 \text { Gy }\end{array}$ & $300 \mathrm{mg}$ & 1 week & RRD grade 2 & $\begin{array}{l}\text { Topical steroids, } \\
\text { Sorafenib } \\
\text { discontinued }\end{array}$ & $\begin{array}{l}\text { Symptoms resolved } \\
\text { after } 10 \text { days }\end{array}$ \\
\hline $\begin{array}{l}\mathrm{Oh}^{\mathrm{a}}, \\
2013\end{array}$ & $50, \mathrm{~m}$ & $\mathrm{HCC}$ & $\begin{array}{l}\text { Chest } \\
\text { wall mass } \\
13 \times 3 \mathrm{~Gy}\end{array}$ & $2 \times 400 \mathrm{mg}$ & 2 weeks & $\begin{array}{l}\text { Erythematous patch, } \\
\text { dry desquamation, } \\
\text { dissemination, } \\
\text { pruritus }\end{array}$ & $\begin{array}{l}\text { Oral } \\
\text { antihistamines, } \\
\text { Sorafenib } \\
\text { discontinued }\end{array}$ & $\begin{array}{l}\text { Sorafenib was restarted, } \\
\text { no recurrent RRD }\end{array}$ \\
\hline $\begin{array}{l}\text { Chung } \\
2010\end{array}$ & $38, \mathrm{~m}$ & $\mathrm{HCC}$ & $\begin{array}{l}\text { Liver SBRT } \\
6 \times 5 \text { Gy }\end{array}$ & $2 \times 200 \mathrm{mg}$ & Several days & $\begin{array}{l}\text { Progressive pruri- } \\
\text { tus, fatigue, patchy } \\
\text { hyperpigmentation, } \\
\text { dry desquamation }\end{array}$ & $\begin{array}{l}\text { Topical steroids, } \\
\text { Sorafenib } \\
\text { continued }\end{array}$ & $\begin{array}{l}\text { Pruritus and skin } \\
\text { changes resolved after } \\
2-3 \text { weeks, } \\
\text { Sorafenib was escalated } \\
\text { without exacerbation } \\
\text { of RRD }\end{array}$ \\
\hline $\begin{array}{l}\text { n.a. }{ }^{b} \\
2008\end{array}$ & $51, \mathrm{~m}$ & $\mathrm{RCC}$ & n.a. & n.a. & n.a. & $\begin{array}{l}\text { Vesicular rash, } \\
\text { swelling, tender- } \\
\text { ness, pain }\end{array}$ & n.a. & n.a. \\
\hline
\end{tabular}

$\overline{H C C}$ hepatocellular carcinoma, $m$ male, $n . a$. not available, $R C C$ renal cell carcinoma, $R R D$ radiation recall dermatitis, $S B R T$ stereotactic radiotherapy 


\section{Conclusion}

$\mathrm{RRD}$ induced by sorafenib is a rare phenomenon. The severity of the reaction seems to be radiation dose dependent (mainly after 30 Gy equivalent dose to the skin). Adverse reactions typically appear 1-2 weeks after commencing sorafenib. Systemic reactions like fever and rash can also occur. RRD is a clinical diagnosis. Histologic sampling might be performed to exclude other causes of skin conditions. Therapy of RRD consists of sorafenib discontinuation, treatment with topical steroids, and/or oral antihistamines. A rechallenge with sorafenib could be considered depending on the clinical situation and grade of dermatitis on a case-by-case basis.

Acknowledgments We thank PD Dr. med. K. Kerl from the Department of Dermatology at the University Hospital Zurich for her consent to publish the histopathologic findings.

\section{Compliance with ethical standards}

Conflict of interest S. Stieb, O. Riesterer, C. Brüssow, B. Pestalozzi, M. Guckenberger, and S. Weiler state that there are no conflicts of interest.

\section{References}

1. Burris HA 3rd, Hurtig J (2010) Radiation recall with anticancer agents. Oncologist 15:1227-1237. doi:10.1634/ theoncologist.2009-0090

2. Product Information: NEXAVAR(R) oral tablets, sorafenib oral tablets. Bayer HealthCare Pharmaceuticals Inc. (per FDA), Whippany, NJ, 2013

3. Bruix J, Raoul JL, Sherman M, Mazzaferro V, Bolondi L, Craxi A, Galle PR, Santoro A, Beaugrand M, Sangiovanni A, Porta C, Gerken G, Marrero JA, Nadel A, Shan M, Moscovici M, Voliotis D, Llovet JM (2012) Efficacy and safety of sorafenib in patients with advanced hepatocellular carcinoma: subanalyses of a phase III trial. J Hepatol 57:821-829. doi:10.1016/j.jhep.2012.06.014

4. Cheng AL, Guan Z, Chen Z, Tsao CJ, Qin S, Kim JS, Yang TS, Tak WY, Pan H, Yu S, Xu J, Fang F, Zou J, Lentini G, Voliotis D, Kang YK (2012) Efficacy and safety of sorafenib in patients with advanced hepatocellular carcinoma according to baseline status: subset analyses of the phase III Sorafenib Asia-Pacific trial. Eur J Cancer 48:1452-1465. doi:10.1016/j.ejca.2011.12.006

5. Lencioni R, Kudo M, Ye SL, Bronowicki JP, Chen XP, Dagher L, Furuse J, Geschwind JF, de Guevara LL, Papandreou C, Takayama T, Yoon SK, Nakajima K, Lehr R, Heldner S, Sanyal AJ (2014) GIDEON (Global Investigation of therapeutic DEcisions in hepatocellular carcinoma and $\mathrm{Of}$ its treatment with sorafeNib): second interim analysis. Int J Clin Pract 68:609-617. doi:10.1111/ijcp.12352

6. Common Terminology Criteria for Adverse Events (CTCAE v4.0). http://evs.nci.nih.gov

7. Laban S, Steinmeister L, Gleissner L, Grob TJ, Grenman R, Petersen C, Gal A, Knecht R, Dikomey E, Kriegs M (2013) Sorafenib sensitizes head and neck squamous cell carcinoma cells to ionizing radiation. Radiother Oncol 109:286-292. doi:10.1016/j. radonc.2013.07.003

8. Jeong YK, Kim MS, Lee JY, Kim EH, Kim W, Ha H, Jeong JH (2013) Sorafenib acts synergistically in combination with radiotherapy without causing intestinal damage in colorectal cancer. Tumori 99:176-182. doi:10.1700/1283.14189
9. Huang CY, Lin CS, Tai WT, Hsieh CY, Shiau CW, Cheng AL, Chen KF (2013) Sorafenib enhances radiation-induced apoptosis in hepatocellular carcinoma by inhibiting STAT3. Int J Radiat Oncol Biol Phys 86:456-462. doi:10.1016/j.ijrobp.2013.01.025

10. Yu W, Gu K, Yu Z, Yuan D, He M, Ma N, Lai S, Zhao J, Ren Z, Zhang X, Shao C, Jiang GL (2013) Sorafenib potentiates irradiation effect in hepatocellular carcinoma in vitro and in vivo. Cancer Lett 329:109-117. doi:10.1016/j.canlet.2012.10.024

11. Kim EH, Kim MS, Jung WG (2014) The mechanisms responsible for the radiosensitizing effects of sorafenib on colon cancer cells. Oncol Rep 32:2421-2428. doi:10.3892/or.2014.3497

12. Peters NA, Richel DJ, Verhoeff JJ, Stalpers LJ (2008) Bowel perforation after radiotherapy in a patient receiving sorafenib. J Clin Oncol 26:2405-2406. doi:10.1200/JCO.2007.15.8451

13. Llovet JM, Ricci S, Mazzaferro V, Hilgard P, Gane E, Blanc JF, de Oliveira AC, Santoro A, Raoul JL, Forner A, Schwartz M, Porta C, Zeuzem S, Bolondi L, Greten TF, Galle PR, Seitz JF, Borbath I, Haussinger D, Giannaris T, Shan M, Moscovici M, Voliotis D, Bruix J, Group SIS (2008) Sorafenib in advanced hepatocellular carcinoma. N Engl J Med 359:378-390. doi:10.1056/ NEJMoa0708857

14. Chen SW, Lin LC, Kuo YC, Liang JA, Kuo CC, Chiou JF (2014) Phase 2 study of combined sorafenib and radiation therapy in patients with advanced hepatocellular carcinoma. Int J Radiat Oncol Biol Phys 88:1041-1047. doi:10.1016/j.ijrobp.2014.01.017

15. Hottinger AF, Aissa AB, Espeli V, Squiban D, Dunkel N, Vargas MI, Hundsberger T, Mach N, Schaller K, Weber DC, Bodmer A, Dietrich PY (2014) Phase I study of sorafenib combined with radiation therapy and temozolomide as first-line treatment of high-grade glioma. Br J Cancer 110:2655-2661. doi:10.1038/ bjc.2014.209

16. Den RB, Kamrava M, Sheng Z, Werner-Wasik M, Dougherty E, Marinucchi M, Lawrence YR, Hegarty S, Hyslop T, Andrews DW, Glass J, Friedman DP, Green MR, Camphausen K, Dicker AP (2013) A phase I study of the combination of sorafenib with temozolomide and radiation therapy for the treatment of primary and recurrent high-grade gliomas. Int J Radiat Oncol Biol Phys 85:321-328. doi:10.1016/j.jirobp.2012.04.017

17. Chiorean EG, Schneider BP, Akisik FM, Perkins SM, Anderson S, Johnson CS, DeWitt J, Helft P, Clark R, Johnston EL, Spittler AJ, Deluca J, Bu G, Shahda S, Loehrer PJ, Sandrasegaran K, Cardenes HR (2014) Phase 1 pharmacogenetic and pharmacodynamic study of sorafenib with concurrent radiation therapy and gemcitabine in locally advanced unresectable pancreatic cancer. Int $\mathrm{J}$ Radiat Oncol Biol Phys 89:284-291. doi:10.1016/j.ijrobp.2014.02.024

18. Aparicio J, Garcia-Mora C, Martin M, Petriz ML, Feliu J, Sanchez-Santos ME, Ayuso JR, Fuster D, Conill C, Maurel J (2014) A phase I, dose-finding study of sorafenib in combination with gemcitabine and radiation therapy in patients with unresectable pancreatic adenocarcinoma: a Grupo Espanol Multidisciplinario en Cancer Digestivo (GEMCAD) study. PLoS One 9:e82209. doi:10.1371/journal.pone.0082209

19. Canter RJ, Borys D, Olusanya A, Li CS, Lee LY, Boutin RD, Christensen SD, Tamurian RM, Monjazeb AM (2014) Phase I trial of neoadjuvant conformal radiotherapy plus sorafenib for patients with locally advanced soft tissue sarcoma of the extremity. Ann Surg Oncol 21:1616-1623. doi:10.1245/s10434-014-3543-7

20. Meyer JM, Perlewitz KS, Hayden JB, Doung YC, Hung AY, Vetto JT, Pommier RF, Mansoor A, Beckett BR, Tudorica A, Mori M, Holtorf ML, Afzal A, Woodward WJ, Rodler ET, Jones RL, Huang W, Ryan CW (2013) Phase I trial of preoperative chemoradiation plus sorafenib for high-risk extremity soft tissue sarcomas with dynamic contrast-enhanced MRI correlates. Clin Cancer Res 19:6902-6911. doi:10.1158/1078-0432.CCR-13-1594 
21. Bramswig K, Ploner F, Martel A, Bauernhofer T, Hilbe W, Kuhr T, Leitgeb C, Mlineritsch B, Petzer A, Seebacher V, Stoger H, Girschikofsky M, Hochreiner G, Ressler S, Romeder F, Woll E, Brodowicz T (2014) Sorafenib in advanced, heavily pretreated patients with soft tissue sarcomas. Anticancer Drugs 25:848-853. doi:10.1097/CAD.0000000000000108

22. WHO Global Database of Individual Case Safety Reports in Pharmacovigilance VigiBase ${ }^{\circledR}$. https://adr.who-umc.org/

23. Hsieh CH, Lin SC, Shueng PW, Kuo DY (2014) Recall radiation dermatitis by sorafenib following stereotactic body radiation therapy. Onco Targets Ther 7:1111-1114. doi:10.2147/OTT.S64706

24. Oh D, Park HC, Lim HY, Yoo BC (2013) Sorafenib-triggered radiation recall dermatitis with a disseminated exanthematous reaction. Radiat Oncol J 31:171-174. doi:10.3857/roj.2013.31.3.171

25. Chung C, Dawson LA, Joshua AM, Brade AM (2010) Radiation recall dermatitis triggered by multi-targeted tyrosine kinase inhibitors: sunitinib and sorafenib. Anticancer Drugs 21:206-209. doi:10.1097/CAD.0b013e328333d679

26. Hird AE, Wilson J, Symons S, Sinclair E, Davis M, Chow E (2008) Radiation recall dermatitis: case report and review of the literature. Curr Oncol 15:53-62

27. Yeo W, Leung SF, Johnson PJ (1997) Radiation-recall dermatitis with docetaxel: establishment of a requisite radiation threshold. Eur J Cancer 33:698-699

28. Stelzer KJ, Griffin TW, Koh WJ (1993) Radiation recall skin toxicity with bleomycin in a patient with Kaposi sarcoma related to acquired immune deficiency syndrome. Cancer 71:1322-1325

29. Phillips TL, Fu KK (1976) Quantification of combined radiation therapy and chemotherapy effects on critical normal tissues. Cancer 37:1186-1200
30. Strumberg D, Richly H, Hilger RA, Schleucher N, Korfee S, Tewes M, Faghih M, Brendel E, Voliotis D, Haase CG, Schwartz B, Awada A, Voigtmann R, Scheulen ME, Seeber S (2005) Phase I clinical and pharmacokinetic study of the Novel Raf kinase and vascular endothelial growth factor receptor inhibitor BAY 43-9006 in patients with advanced refractory solid tumors. J Clin Oncol 23:965-972. doi:10.1200/JCO.2005.06.124

31. Camidge R, Price A (2002) Radiation recall dermatitis may represent the Koebner phenomenon. J Clin Oncol 20:4130, author reply 4130

32. Masri SC, Misselt AJ, Dudek A, Konety SH (2014) Radiation recall reaction causing cardiotoxicity. J Cardiovasc Magn Reson 16:25. doi:10.1186/1532-429X-16-25

33. Boussemart L, Boivin C, Claveau J, Tao YG, Tomasic G, Routier E, Mateus C, Deutsch E, Robert C (2013) Vemurafenib and radiosensitization. JAMA Dermatol 149:855-857. doi:10.1001/ jamadermatol.2013.4200

34. Forschner A, Zips D, Schraml C, Rocken M, Iordanou E, Leiter U, Weide B, Garbe C, Meier F (2014) Radiation recall dermatitis and radiation pneumonitis during treatment with vemurafenib. Melanoma Res 24:512-516. doi:10.1097/CMR.0000000000000078

35. Dauendorffer JN, Dupuy A (2009) Radiation recall dermatitis induced by erlotinib. J Am Acad Dermatol 61:1086. doi:10.1016/j. jaad.2009.04.033

36. Levy A, Hollebecque A, Bourgier C, Loriot Y, Guigay J, Robert C, Delaloge S, Bahleda R, Massard C, Soria JC, Deutsch E (2013) Targeted therapy-induced radiation recall. Eur J Cancer 49:16621668. doi:10.1016/j.ejca.2012.12.009 